\title{
Astma i toppidretten - fra 1960-årene til i dag
}

\author{
Astmadiagnostikk og behandling av toppidrettsutøvere er blitt en utfordring. For meg startet det hele i 1960 - \\ årene, som sykehuslege for barn og unge med astma som hadde store problemer med å være fysisk aktive. \\ Dette er min historie som landslagslege, slik jeg husker den.
}

Rundt 1965 kom de første beta-2-agonistene til inhalasjon på markedet. I 1972 fikk jeg være med på utprøvning av Becotide (beklometason), det første inhalasjonssteroidet - et medikamentelt prinsipp som skulle revolusjonere astmabehandlingen ved å dempe inflammasjonen i luftveiene.

Man hadde allerede fra begynnelsen av 1950-årene vist at systemiske steroider kunne ha god effekt $\mathrm{i}$ behandlingen av astma (1). Vi oppdaget snart at med god medisinering som dempet inflammasjonen var fysisk aktivitet for astmatikerne ikke bare mulig, men ga en stor helsegevinst. Idrettsutøvere med astma kunne etter hvert konkurrere på bra nivå med inhalasjonssteroider som grunnbehandling og beta-2agonister som tilleggsbehandling eller premedikasjon før trening og konkurranser,
Etter hvert ble vi klar over at tidligere friske utøvere av kondisjonskrevende idretter som trente intensivt (kanskje 20-25 mil per uke, f.eks. langdistanse i friidrett, lang-

\section{«Toppidretten har fjernet seg mer og mer fra idealet om at idrett er sunt»}

renn og sykkel) spesielt i sterk kulde og etter virusinfeksjoner fikk astmalignende plager med pustebesvær. Og videre at hard fysisk aktivitet ved ekstrem luftforurens-

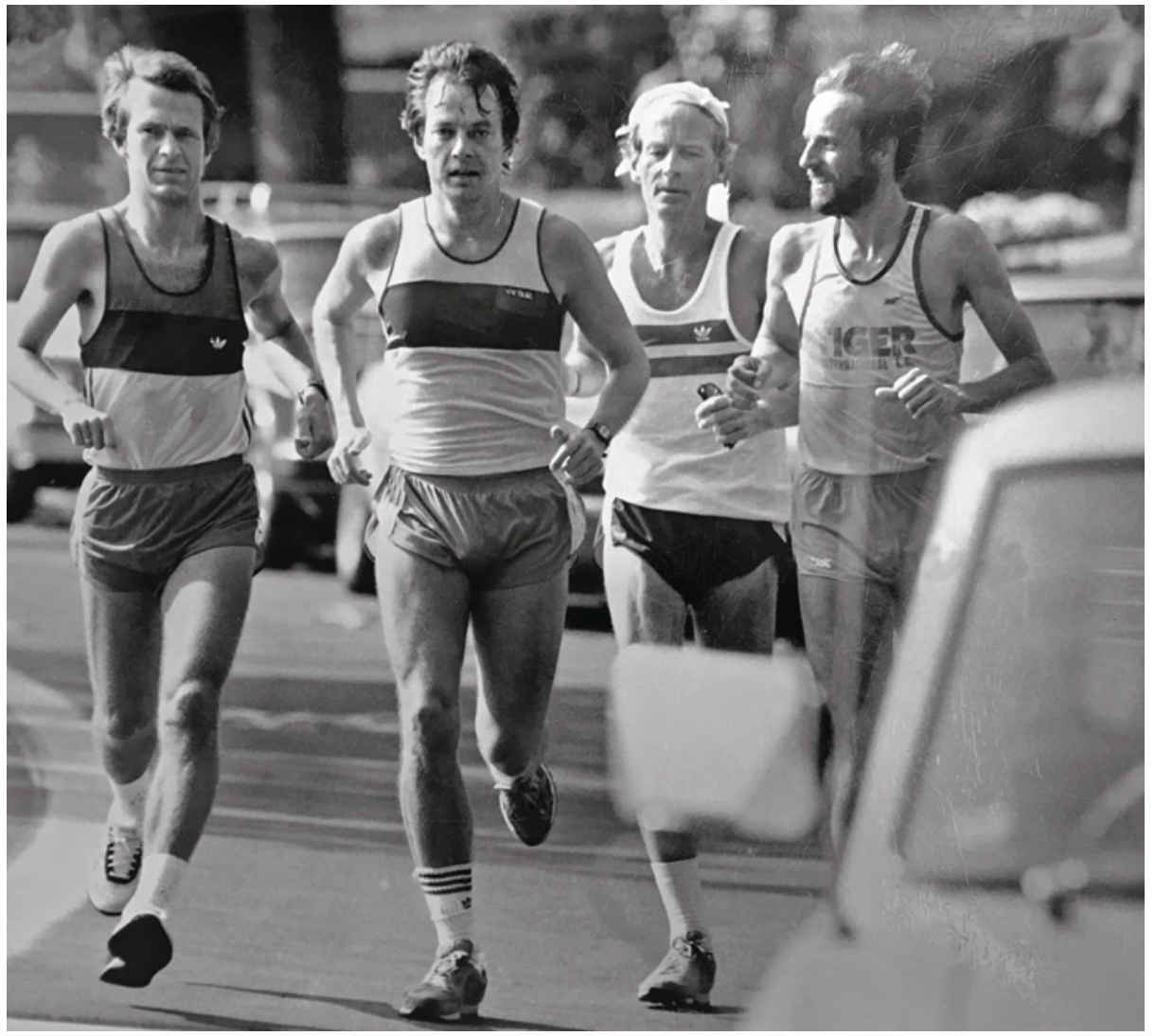

Figur 1 Forfatteren er ute og tester 25 kilometer av maratonløypa i sterk varme og forurenset luft. Fra høyre Lasse Virén (finsk OL-vinner på 10000 meter), Thor-Øistein Endsjø, Alf H. Fredstad og Jack Waitz. Foto: HansOlav Forsang/VG/NTB scanpix ning kunne føre til bronkial hyperreaktivitet og såkalt idrettsastma, men at det også kunne redusere den fysiske yteevnen (2).

Sommerlekene i Los Angeles i 1984 Luftkvaliteten i Los Angeles var en utfordring for Den internasjonale olympiske komité (IOC) (3). Luftutvekslingen var lav i storbyen, som var omgitt av høye åser og skråninger. Målinger viste at det på solfylte, vindstille sommerdager kunne bli høye konsentrasjoner av ozon, NO, CO og partikkelstøv. Konsentrasjonene kunne være så høye at pasienter med hjerte-lunge-sykdom ble rådet til å oppholde seg innendørs.

Ozon er et ustabilt molekyl, sammensatt av tre oksygenmolekyler. Det dannes ved at solstrålene initierer en reaksjon mellom nitrogenoksid, oksygen og flyktige hydrokarboner som finnes i avgasser fra biltrafikk og industri. Økede mengder ozon kan føre til nedsatt lungefunksjon og inflammasjon i luftveiene. På den bakgrunn ble det i Leepsons rapport diskutert om det i det hele tatt var forsvarlig å gjennomføre kondisjonskrevende øvelser under slike forhold (3). Det ble også diskutert om man skulle anbefale at selv friske utøvere i noen dager skulle premedisineres med inhalasjonssteroid og beta2-agonist.

Sammen med kollega Svein Oseid hadde jeg et møte med den australske professoren Ken Fitch, hvor vi ble enige om å tilby de norske utøverne i kondisjonskrevende øvelser tre dager med inhalasjonsbehandling, inkludert konkurransemorgenen. I etterkant er jeg i tvil om slik kortvarig behandling kunne ha noen forebyggende effekt, men vi hadde tro på det der og da. At for eksempel maraton i Los Angeles var en spesielt krevende øvelse, ble understreket av at mange utøvere var totalt utmattet: $10-15$ løpere ble behandlet med intravenøst drypp i målområdet. Om dette bare skyldtes sterk varme og dehydrering, er jeg fortsatt usikker på.

Den enkleste av alle spirometriske undersøkelser, måling av toppstrømshastighet (peak expiratory flow, PEF), det vil si hastigheten på den maksimale utpust $\mathrm{i}$ liter per minutt, kan gi en liten pekepinn på bronkial obstruksjon. For å teste virkningen av luften i Los Angeles før OL-konkurransene 
var vi fire stykker som løp 15-20 kilometer $\mathrm{i}$ rolig tempo (fig 1, fig 2). Vi hadde alle fire fallende PEF-verdier samtidig som vi opplevde at slimhinnene i luftveiene ble tørre og irriterte på tross av rikelig drikke. Disse observasjonene tok vi til inntekt for at det var nødvendig å ta luftforurensningen på alvor og at tilbud om forebyggende behandling, spesielt før maraton, var nødvendig.

\section{Etiske betenkeligheter}

Hadde vi etiske betenkeligheter? Både da og nå har jeg betraktet denne legevirksomheten som yrkesmedisin i toppidretten. Det beste hadde selvsagt vært å si at maraton under slike forhold er helseskadelig og at løpet ikke burde arrangeres. Slik er imidlertid ikke virkeligheten. I den virkelige verden er kravene til hurtigere, lengre, høyere også et krav innen medisinen.

Vi har ikke klart å bremse denne utviklingen, og toppidretten har fjernet seg mer og mer fra idealet om at idrett er sunt. Støtteapparatet rundt utøverne har da som oppgave først og fremst å legge forholdene til rette slik at helseskade så langt det er mulig kan unngås - uten at prestasjonene forringes. Tre dagers bruk av inhalasjonsmedisin kunne i beste fall fore til normalisering av lungefunksjonen. Kanskje hadde det ingen effekt i det hele tatt? Noen prestasjonsfremmende effekt utover dette så vi som helt utelukket.

\section{Langrennsløperne}

De neste utfordringene kom vinteren 1984/ 85 med langrennsløperne. Til rådighet hadde jeg både ergometersykkel, tredemølle og et godt spirometer for testing av anstrengelsesutløst astma. De første jeg fikk til testing, kunne fortelle om typisk idrettsastma: På ski i kulde følte de at det ble trangt $\mathrm{i}$ brystet, ofte med hoste, og de orket mindre.

Noen av dem gikk med subobstruksjon som kunne reverseres med inhalasjon av beta-2-agonist. Andre hadde normale spirometrikurver i ro, men ble obstruktive i løpet av seks-syv minutter på tredemølle. Andre igjen merket bare pusteproblemene ved belastning ute. Jeg har vært ute sammen med utøvere og stilt diagnosen bronkial obstruksjon med medbrakt stetoskop og PEF-måler. Slik kunne reversibilitet testes med inhalasjon av en beta-2-agonist i sprayform.

Noen av våre beste langrennsløpere hadde problemer med pusten vinteren 1985. Den ene hadde hatt allergisk astma helt fra barneårene, med bedring $\mathrm{i}$ ungdomsårene. Etter virusinfeksjoner og ved trening/konkurranser i sterk kulde kunne astmaen dukke opp igjen. Dette skjedde igjen denne vinteren, og spirometri med reversibilitet etter beta-2- agonist bekreftet en labil astmasituasjon. Etter få dager med inhalasjonssteroid og beta-2-agonist var sesongen reddet.

Den andre bar mer preg av 20 års trening og mange konkurranser i til dels sterk kulde. De siste sesongene hadde vært preget av varierende prestasjoner og en subjektiv opplevelse av at pusten ikke var god. Grundig utredning med anstrengelsestest på tredemølle og spirometriske undersøkelser med reversibilitet viste mer eller mindre kronisk obstruksjon, som ble verre i skiløypa. Igjen snudde inhalasjonssteroid og beta-2-agonist den dårlige tendensen, og utøveren fikk på nytt noen gode sesonger.

At noen toppidrettsutøvere fikk astmabehandling, ble etter hvert godt kjent i idrettsmiljøene. Det ble også tydelig at enkelte hadde svært god effekt av behandlingen. Det var nærliggende for unge idrettsutøvere som følte at de fikk piping og tung pust ved anstrengelser å tro at de hadde astma.

For de fleste kunne det ikke påvises bronkial obstruksjon ved hjelp av klinisk undersøkelse, spirometri og reversibilitetstest. Enkelte syntes ikke de hadde den fremgangen i idretten sin de skulle ønske seg og mente derfor det kunne skyldes at de hadde astma. For mange av disse ungdommene dreide det seg om dårlig pusteteknikk - symptomene bedret seg etter instruksjon i å puste riktig. Andre fikk en laryngeal stridor som til forveksling kunne minne om piping ved astma når pulsen økte over et visst nivå ved hardtrening.

I ettertid er det klart at vi ikke hadde nok erfaring da vi vurderte dosene av inhalasjonssteroider, behandlingslengde og eventuelle pauser i behandlingen av toppidrettsutøvere. De første inhalasjonssteroidene som kom på markedet, hadde en mer uttalt systemeffekt enn de som brukes i dag. Sammenhengende behandling med relativt høye doser kunne få uheldige effekter på bentetthet og spontanfrakturer.

\section{Skøyteløperne}

Fra 1980-årene og senere var jeg medisinsk ansvarlig i Norges Skøyteforbund i to perioder. Skøytesport var da blitt en innendørs hallidrett. Luften i skøytehallene inneholdt rikelig med irritanter, dels fra islegging og dels fra bensin-/gassdrevne isprepareringsmaskiner. Frisklufttilførsel og ventilasjon var ofte mangelfull på grunn av energisparing.

For å knipe skøyteløpere med bronkial obstruksjon måtte vi bruke PEF-måling og stetoskop i skøytehallen. Vi oppdaget at ved bruk av inhalasjonssteroider ble symptomene (hoste og sliming) redusert og PEF-verdiene normalisert. Etter konkurranser kunne løperne oppleve at luftveiene

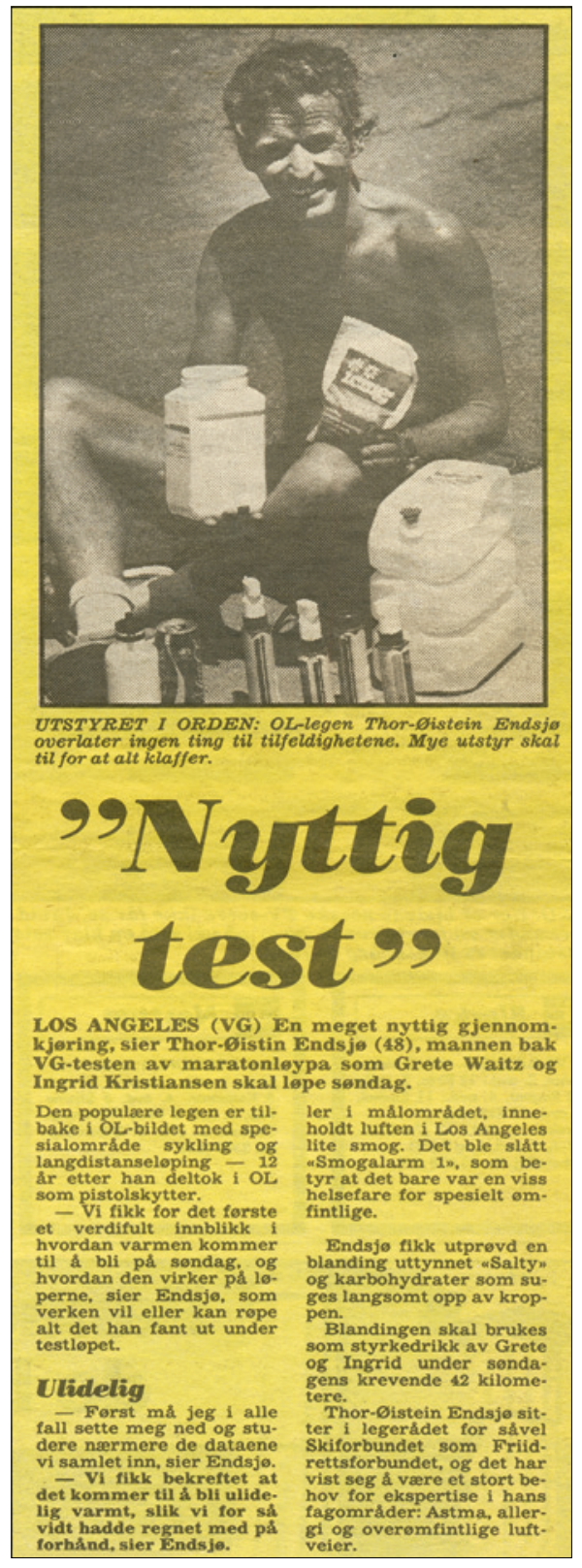

Figur 2 «Nyttig test», sa Thor- Øistein Endsjø etterpå. Faksimile fra VG 2. august 1984

var helt nedhøvlet, såre og rå. Vi brukte fysiologisk saltvann i forstøverapparat rett etter konkurranser, noen ganger med tillegg av inhalasjonssteroider. Dette så vi hadde god effekt - utøverne kom seg raskere og var ikke i like stor grad utsatt for luftveisinfeksjoner.

Men spørsmålet blir stående: Behandlet vi friske utøvere, altså ikke-astmatikere, med astmamedisiner? Vi erfarte at virale luftveisinfeksjoner om vinteren med hoste og ekspektorat med fordel kunne behandles med inhalasjonssteroider og beta-2-agonister. Det dreide seg da om en til to ukers behandling, selvsagt utenfor konkurranser. Slik la vi forholdene til rette for at utøverne 
raskere ble friske - uten at behandlingen ga noe konkurransefortrinn.

\section{Glemt kunnskap?}

Hva med diagnostikk og behandling av astma i idretten for 30-40 år siden sammenlignet med i dag? I dag vurderes bronkial hyperreaktivitet med metakolintest, eventuelt sammen med ekshalert NO, og moderne spirometri. Definerte grenseverdier sammen med testing på tredemølle/ ergometersykkel blir avgjørende for å stille en astmadiagnose. Dette gir en grundigere og sikrere utredning. Men samtidig: Mister vi noen som kan oppdages med klinisk vurdering og utendørs enkel spirometri med PEF-måler?

Hovedprinsippene $\mathrm{i}$ behandlingen er de samme i dag som den gang: Grunnbehandling av inflammasjonen i bronkiene med inhalasjonssteroider og tilleggsbehandling med beta-2-agonister ved behov. Vi vektla grunnbehandlingen og prøvde å periodisere bruken av beta-2-agonister til ekstra dårlige perioder og som premedikasjon før hard fysisk aktivitet.

Vi ble tidlig klar over at beta-2-agonister i store doser kunne gi takykardi, generell uro og i enkelte tilfeller fremprovosere muskelkramper. Store doser over lengre tid kunne også føre til at effekten av premedikasjon (f.eks. før konkurranser) avtok, senere dokumentert som uttretting av reseptorene i bronkiene - takyfylaksi. Denne effekten ble enda mer uttalt da noen introduserte langtidsvirkende beta-2-agonister (såkalte LABA-er) i toppidretten.

Beta-2-agonisten Clenbuterol var registrert i Mellom-Europa som humanmedisin, men ble i Skandinavia bare registrert som veterinærmedisin (i 1993). Clenbuterol viste seg å ha uheldige virkninger $\mathrm{i}$ andre organer enn lungene ved at den virket både

\section{«Behandlet vi}

\section{friske utøvere, altså ikke-astmatikere, med astmamedisiner?»}

anabolt og sentralstimulerende (4). Den ble misbrukt av kroppsbyggere og andre som ønsket slike tvilsomme effekter i de landene den var registrert.

At beta-2-agonister generelt kunne ha slike virkninger, har nok ført til større varsomhet med store doser av slike preparater i humanmedisinen. For eksempel ble det $i$ en studie vist at salbutamol i store doser hadde en anabol effekt (5). Andre har ikke kunnet vise det samme. Dette er vel egentlig ikke bare historie, men synes å være et aktuelt problem i dag også.
De to langrennsløperne som er omtalt her, har gitt samtykke til at manuskriptet blir publisert.

\section{Thor-øistein Endsjø}

tendsjo@hotmail.com

Thor-Øistein Endsjø (f. 1936) er pensjonert idrettsmedisiner.

Forfatter har fylt ut ICMJE-skjemaet og oppgir ingen interessekonflikter.

Litteratur

1. Morgan WK, Rusche E. A controlled trial of the effect of steroids in obstructive airways disease. Ann Intern Med 1964; 61: 248-54.

2. Holtzman MJ, Fabbri LM, O'Byrne PM et al. Importance of airway inflammation for hyperresponsiveness induced by ozone. Am Rev Respir Dis 1983, 127: $686-90$

3. Leepson M. Olympics 1984: Countdown to Los Angeles. Editorial research reports 1984 (Vol. I). Washington D.C.: CQ Press, 1984. http://library. cqpress.com/cqresearcher/document.php?id= cqresrre1984052500 (21.11.2016).

4. Sneddon AA, Delday MI, Steven J et al. Elevated IGF-II mRNA and phosphorylation of 4E-BP1 and p70(S6k) in muscle showing clenbuterol-induced anabolism. Am J Physiol Endocrinol Metab 2001; 281: E676-82.

5. Martineau L, Horan MA, Rothwell NJ et al. Salbutamol, a beta 2-adrenoceptor agonist, increases skeletal muscle strength in young men. Clin Sci (Lond) 1992; 83: 615-21.

Mottatt 8.11. 2016, første revisjon innsendt 29.11. 2016, godkjent 30.11. 2016. Redaktør: Ketil Slagstad. 